Chirurgia (2018) 113: $571-575$

No. 4, July - August

Copyright $@$ Celsius

http://dx.doi.org/10.21614/chirurgia.113.4.571

\title{
A Rare Case of Intestinal Obstruction in an Elderly Woman
}

\author{
Matei R. Bratu ${ }^{1,2}$, Bogdan Balmes ${ }^{1}$, Bogdan I. Diaconescu ${ }^{1,2}$, Mircea Beuran ${ }^{1,2}$ \\ 'Department of General Surgery, "Floreasca" Emergency Clinical Hospital of Bucharest, Bucharest, Romania \\ 2"Carol Davila" University of Medicine and Pharmacy, Bucharest, Romania
}

Corresponding author:

Bogdan I. Diaconescu, Lecturer, MD, PhD Department of General Surgery

"Floreasca" Emergency Clinical Hospital Calea Floreasca Street, no. 8, district 1 Bucharest, Romania

E-mail: bogdan.diaconescu@yahoo.com

\section{Rezumat}

\section{Un caz rar de ocluzie intestinală la o pacientă vârstnică}

Dintre cazurile de ocluzie intestinală la adult, invaginația este una dintre cele mai rare etiologii. Atunci când apare se manifestă prin durere abdominală, vărsături şi alte simptome specifice localizării invaginației. Comparativ cu invaginația la copil, care cel mai frecvent este idiopatică, cazurile la adult prezintă o etiologie organică, cu o simptomatologie nespecificăşi necesită investigații imagistice avansate pentru un diagnostic precis. Vom prezenta cazul unei paciente în vârstă de 70 de ani cu multiple prezentări la Departamentul de Urgență pentru dureri abdominale şi vărsături, pacientă care a fost diagnosticată doar la a treia prezentare. Ecografia abdominalăşi radiografia abdominală simplă nu au prezentat modificări şi tomografia computerizată a evidențiat cauza reală a ocluziei. De asemenea, managementul conservator a fost ineficient şi invaginația a necesitat enterectomie cu anastomoză primară. Rezultatul histopatologic a evidențiat o tumoră benignă de jejun proximal. În concluzie, invaginația intestinală a adultului, deşi este o patologie rară, se poate prezenta cu o simptomatologie nespecifică variind în funcție de localizarea invaginației. Comparativ cu cazurile pediatrice, cazurile întâlnite la adult necesită de cele mai multe ori intervenție chirurgicală.

Cuvinte cheie: ocluzie intestinală, invaginație, caz rar

\section{Abstract}

Among intestinal obstruction, intussusception is one of the rare 
mechanical causes in the adult period. When it is met it present with abdominal pain, vomiting and other symptoms compatible with intestinal obstruction varying on the segments being involved. Compared to pediatric invagination which it is mostly idiopathic the adult form has an organic etiology causing a blurred symptomatology and needing advanced imaging diagnosis like computerized tomography. We present the case of a 70 year old woman with multiple Emergency Department presentations with abdominal pain and vomiting which received a clear diagnosis only the third time she came to hospital. Ultrasonography and plain abdominal x-ray were no specific and only the CT scan revealed the real cause of obstruction. Also conservative measures were useless the definitive treatment being surgery, the lesion necessitating enteral resection and end to end anastomosis. The pathology report revealed a benign tumor of proximal jejunum. In conclusion, adult intestinal invagination, although it is a rare condition, can present with symptomatology varying with segment of bowel involved into the intussusception. Unlike pediatric invagination, the adult one needs standard surgical revision unless there are certain contraindications.

Key words: intestinal obstruction, intussusception, enteric invagination, rare case

\section{Introduction}

Many years have passed by since Barbette of Amsterdam described the first intestinal invagination (in 1674) (1) and Sir Jonathan Hutchinson operated a child with the same pathology in 1871 (1). Intestinal invagination or intussusception is the telescoping of the proximal intestine into the distal part mainly because of its peristaltic movements. It is most often seen in children and rarely in adults, accounting $1-5 \%$ of intestinal obstructions in this age group. Also when it appears into adulthood it is most of the time because of a pathological cause, like tumors or adhesions. This is why in $70-90 \%$ of the cases, intussusception needs a definitive surgical treatment (2). It is classified by the pathologic lesion leading to invagination or by the segments involved (ileo-colic, ileo-ileal, colo-colic etc.) and the diagnosis is most of made by CT.

\section{Case Presentation}

A 70 years old woman presents to the Emergency Department for epigastric pain irradiating to the left upper quadrant accompanied by nausea and vomiting. From anamnesis we found that this is the 3rd episode of abdominal pain this month but the previous two were insignificant compared to the present one. The colicky pain started 24 hours ago in the epigastric region with left upper quadrant irradiation and it became more intense and frequent in the last 3 hours when nausea and gastric content vomiting appeared. Also, she states that all these episodes were after consistent meals and were not influenced by defecation. The patient is known with arterial hypertension and colonic diverticulosis (without any episodes of diverticulitis) and she negates any history of gastro-duodenal or biliary pathology and she has no previous surgical intervention.

At admission to the Emergency Department, the patient had a slightly tachycardia with a pulse rate of $92 \mathrm{bpm}$ and an arterial pressure of 150 with $90 \mathrm{mmHg}$. There were no electrocardiographic modifications. At physical examination the patient had a mild distended abdomen with colicky pain with maximum of intensity in the epigastric region and irradiation in the left upper quadrant, with mild enhancement at palpation but no signs of peritoneal irritation. The abdominal sounds were normal. The digital rectal examination and clinical genital exploration was normal, so was the clinical evaluation of the other systems.

Blood samples showed a mild leukocytosis $(12000 / \mu \mathrm{L})$ with no other modifications. Also abdominal X-ray was normal. Ultrasono-graphic exploration of the abdomen revealed some 
intraperitoneal liquid of $25 \mathrm{~mm}$ in the left abdominal flank and no other modifications.

After the patient is hospitalized an upper endoscopy showed no gastroduodenal pathology; a computerized tomography was performed and revealed important gastric stasis and in the left flank a jejuno-jejunal invagination with proximal intestines very dilated (Fig. 1, 2, 3) and intraperitoneal liquid of $30 \mathrm{~mm}$ in the Douglas pouch. Also it showed sigmoid diverticula with no inflammation and a uterine fibroma.

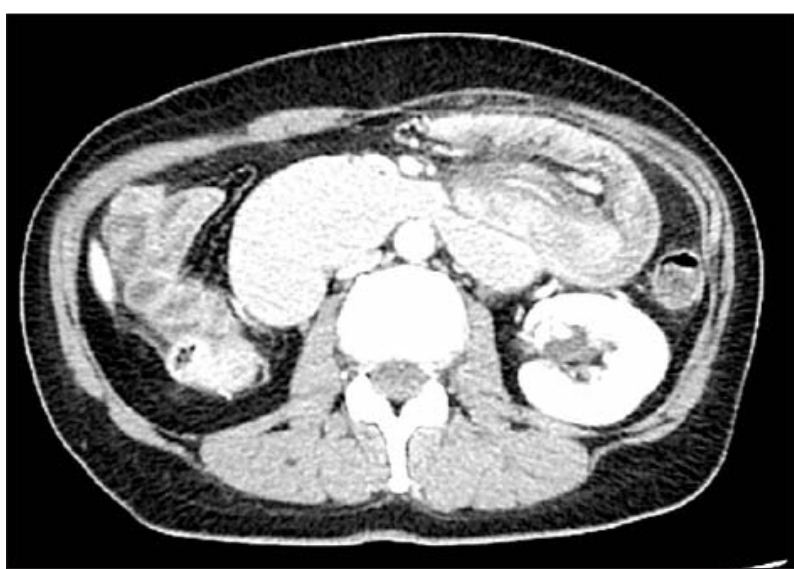

Figure 1. A CT-scan aspect of intussusception-Transverse section showing entero-enteral invagination with mesenteric vessels inside bowel lumen

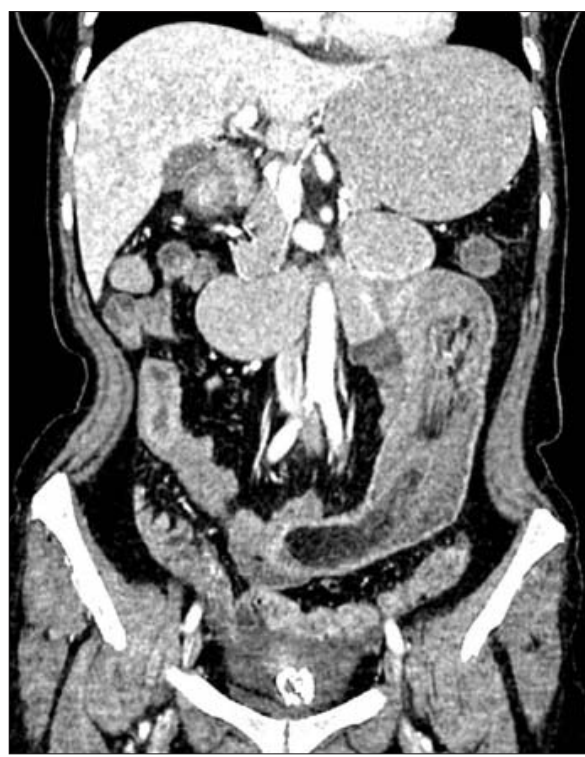

Figure 3. CT-scan of intussusception-Coronal section showing invaginated bowels in left flank
Considering the symptomatology and CT findings, after the patient signed the informed consent and has been prepared for surgery we performed an exploratory laparotomy and discovered a jejuno-jejunal anterograde invagination on a distance of $25 \mathrm{~cm}$ with moderate edema on both bowels segments (Fig. 4); we reduced the invagination and found a voluminous polyp on the mesenteric border (Fig. 5, 6). A segmental enterectomy was performed with an end to end anastomosis.

Postoperative evolution was simple and the

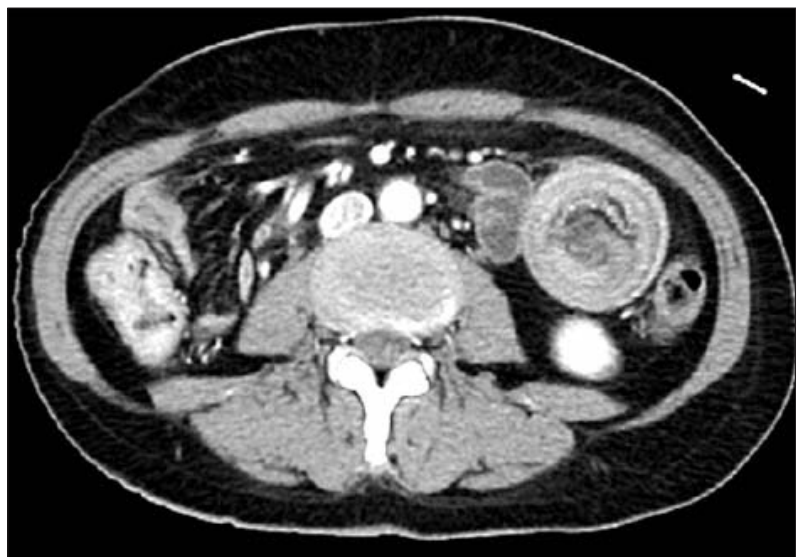

Figure 2. A CT-scan aspect of intussusception - Transverse section showing encircled rings of bowels invaginated

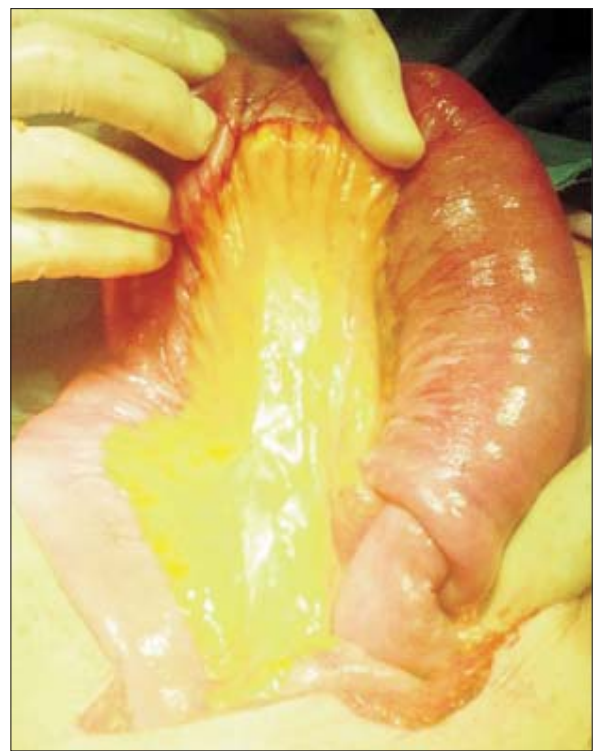

Figure 4. Intraoperative findings - Jejunojejunal invagination with edematous walls $(25 \mathrm{~cm})$ 


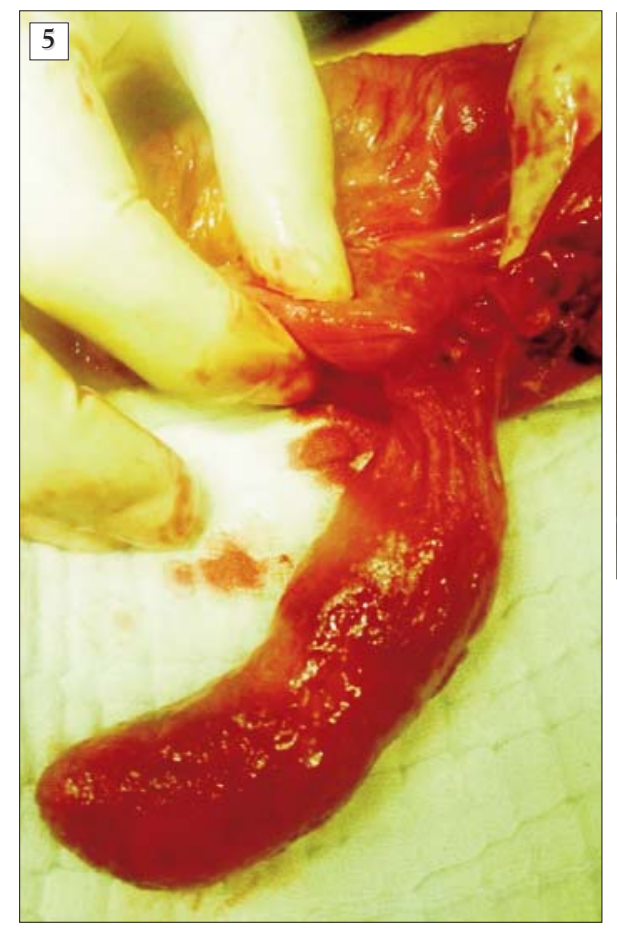

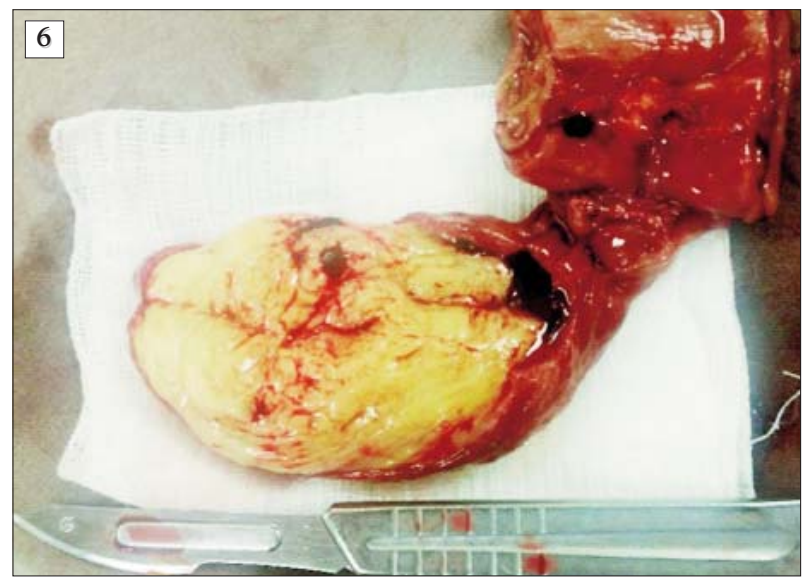

Figure 5. Intraoperative findings - A large polyp on the mesenteric border of the jejunum causing invagination (enterotomy finding)

Figure 6. Polyp tumor of jejunum- Macroscopic appearance as a lipoma also confirmed by pathology report patient was discharged on the fourth day. The pathologic report revealed a benign lipomatous tumor.

\section{Discussion}

Classically, intussusception is a pediatric emergency with a high frequency in this age group, being one of the first differential diagnosis to think in an intestinal obstruction. The triad of colicky intermittent episodes of pain, "red jelly" stools and palpable abdominal mass makes an easy to diagnose pathology in children. Unfortunately, adult intestinal invagination is a rare condition with a blurry symptomatology. When a patient comes with signs of intestinal obstruction, intussusception is the last in the list of differential diagnosis. Palpable abdominal mass was found out in $47 \%$ of the patients with a colonic lesion and $14 \%$ of the patients with an enteric lesion (3). Fifty percent of the patients had symptoms for more than 3 weeks before presentation to the hospital. Most of the patients (73\%) with colonic intussusceptions had a duration of symptoms of more than 10 days (3). Also, pre- operative diagnosis for enteric intussusception was $41 \%$ reported by Barussaud et al (3) and smaller than $40.7 \%$ reported by Eisen et al (4). Our patient had 2 more presentations in the Emergency department with the same features and no clear diagnosis was made. Current imagistic investigations like x-ray have a high sensibility only for those cases presenting with frank intestinal obstruction (sensibility of $82 \%$ ) (5), but for cases like ours with upper gastrointestinal obstruction x-ray proved useless for three times (the patient had 3 plain abdominal x-rays). Also ultrasound proved as a very efficacious tool in pediatric intussusception with very high specificity and sensibility (97\% and $85 \%$ ) (6) and also in some adult studies [86.6\% for Gupta R. et al (7)]. In our adult case ultrasonography revealed some intraperitoneal excessive liquid being without specificity.

The diagnosis was clearly made with a CTscan revealing a "target" sign and mesenteric vasculature inside a bowel. In literature CT scan has high accuracy in diagnosis of this pathology between $58-100 \%(3,8)$. CT can predict the primary lesion and show metastases 
in case of malignancy. In adult intussusception there is an organic cause in $70-90 \%$ of the cases $(9,10$, and 11$)$ and $66 \%$ of them are malignant (3). The most frequent location are enteric invaginations. Given these data all diagnosed intussusceptions in adult should be surgically managed. The procedure must be adapted according to the lesion, size and location. Also the surgical treatment can be performed by laparotomy or laparoscopy. Lebeau et al. (12) and Barrusaud et al. (3) reported mortality rates of $15 \%$ and $16 \%$ while Chang et al. (13) had an overall mortality rate of $4.3 \%$.

\section{Conclusions}

Adult intestinal intussusception is a disease that most of the time is not diagnosed at the first presentation because of the non-specific presentation. However, deep understanding of the mechanism correlated with an accurate anamnesis and high index of suspicion must orientate the clinician to the idea that intestinal invagination could appear also to an older person and that most of the time it has an organic etiology. Regarding the treatment, there is no consensus whether to operate immediately, as a late emergency or to try the reduction of invagination by conservative measures, however the surgeon should keep in mind that even if the conservative measures are successful, due to the specific etiology, the intussusception can repeat making the surgical treatment a more logical option.

\section{Acknowledgement}

We thank to doctor Racoveanu from Imaging Departement of our hospital for making such an accurate diagnosis on $\mathrm{CT}$ images.

\section{Conflicts of Interest}

None declared.

\section{Authors' Contributions}

Matei Bratu - materials gathering, writing of article. Bogdan Balmes - materials gathering, writing of article. Bogdan Diaconescu - materials gathering, writing of article. Mircea Beuran article writing, reviewing.

\section{References}

1. Marinis A, Yiallourou A, Samanides L, Dafnios N, Anastasopoulos G, Vassiliou I, et al. Intussusception of the bowel in adults: A review. World J Gastroenterol 2009:15(4):407-11.

2. Begos DG, Sandor A, Modlin IM. The diagnosis and management of adult intussusception. Am J Surg. 1997;173(2):88-94.

3. Barussaud M, Regenet N, Briennon X, de Kerviler B, Pessaux P, Kohneh-Sharhi N, et al. Clinical spectrum and surgical approach of adult intussusceptions: a multicentric study. Int J Colorectal Dis. 2006;21(8):834-9.

4. Eisen LK, Cunningham JD, Aufses AH Jr. Intussusception in adults: institutional review. J Am Coll Surg. 1999:188(4):390-5.

5. Lindor RA, Bellolio MF, Sadosty AT, Earnest F 4th, Cabrera D. Adult intussusception: presentation, management, and outcomes of 148 patients. J Emerg Med. 2012;43(1):1-6.

6. Riera A, Hsiao AL, Langhan ML, Goodman TR, Chen L. Diagnosis of intussusception by physician novice sonographers in the emergency department. Ann Emerg Med. 2012;60(3):264-8.

7. Gupta RK, Agrawal CS, Yadav R, Bajracharya A, Sah PL. Intussusception in adults: institutional review. Int J Surg. 2011; 9(1):91-5.

8. Wang LT, Wu CC, Yu JC, Hsiao CW, Hsu CC, Jao SW. Clinical entity and treatment strategies for adult intussusceptions: 20 years' experience. Dis Colon Rectum. 2007;50(11):1941-9.

9. Azar T, Berger DL. Adult intussusception. Ann Surg. 1997;226(2): 134-8.

10. Reijnen HA1, Joosten HJ, de Boer HH. Diagnosis and treatment of adult intussusception. Am J Surg. 1989;158(1):25-8.

11. Martín-Lorenzo JG, Torralba-Martinez A, Lirón-Ruiz R, FloresPastor B, Miguel-Perelló J, Aguilar-Jimenez J, et al. Intestinal invagination in adults: preoperative diagnosis and management. Int J Colorectal Dis. 2004;19(1):68-72.

12. Lebeau R, Koffi E, Diané B, Amani A, Kouassi JC. Acute intestinal intussusceptions in adults: analysis of 20 cases. Ann Chir. 2006;131(8):447-50. French

13. Chang CC, Chen YY, Chen YF, Lin CN, Yen HH, Lou HY. Adult intussusception in Asians: clinical presentations, diagnosis, and treatment. J Gastroenterol Hepatol. 2007;22(11):1767-71. 